\title{
Seasonal Variation on the Hydrochemistry and Height of Brackish-Water from Commodore Channel, Lagos, Nigeria
}

\section{Samuel Olatunde Popoola*, John-Paul Unyimadu, Ayoola Olubunmi Nubi, Oluwaseun Adedayo Adeleye, Ismaila Ayinde Oba, Karo Oghenede Esther, Salisu Adamu, Moromade Abibat Lere-Aliu, Taofeek Olawale Olabiyi, Akintunde Adewole Adegbite, Abdulmujeeb Bolaji Hamzat, Ekundayo Oluwaseun Adeyemi and Solomon Mordi}

Department of Physical and Chemical Oceanography, Nigerian Institute for Oceanography and Marine Research, PMB, 12729, Victoria Island, Lagos, Nigeria

*Corresponding author's e-mail: popoolaos@niomr.gov.ng

\section{Abstract}

The current study deals with the evaluation of physicochemical characteristics, nutrient status, and variation in the height of surface water from the commodore channel, and its comparison with the hydrochemical characteristics of the monitoring borehole from the NIOMR Jetty, Lagos, Nigeria. We aim to further improve our understanding of the interrelationship of climate change and hydrological cycle, and its impacts in the Lagos coastal environments. The observed ranges of physicochemical characteristics of the surface water are dissolved oxygen (DO) 3.07-6.05mg/L; $\mathrm{pH}$ : 7.99-8.48; temperature 26.97-30.34 ${ }^{\circ} \mathrm{C}$, electrical conductivity (EC) $9680-47800 \mathrm{mS} / \mathrm{cm}$; salinity (Sal) $6.51-$ $28.05 \%$ and water level $1.24-1.79 \mathrm{~m}$. The concentration of nutrient range from nitrite 10 $36 \mathrm{mg} / \mathrm{l}$, nitrate $28-44 \mathrm{mg} / \mathrm{l}$, sulphate $38-90 \mathrm{mg} / \mathrm{l}$ and phosphate $2-78 \mathrm{mg} / \mathrm{l}$. The analyzed hydrochemical characteristics from all the stations are within the desired values for healthy marine ecosystems when compared with Federal Ministry of Environment (FMENV) Nigeria permissible limits which are: DO $>5 \mathrm{mg} / 1, \mathrm{pH} 6.5-9$, temperature $<40^{\circ} \mathrm{C}$, nitrite $1 \mathrm{mg} / \mathrm{l}$, nitrate $20 \mathrm{mg} / \mathrm{l}$, phosphate $5 \mathrm{mg} / 1$ and sulphate $500 \mathrm{mg} / \mathrm{l}$; except low DO $(<4.5 \mathrm{mg} / \mathrm{l})$ in January, November and December, and elevated nitrite, nitrate and phosphate values across the season. The low DO values may be attributed to enhanced

\section{Received: November 14, 2020; Accepted: December 12, 2020}

Keywords and phrases: hydrochemical characteristics, surface water, groundwater, climate change, commodore channel, Nigeria.

Copyright (C) 2021 Samuel Olatunde Popoola et al. This is an open access article distributed under the Creative Commons Attribution License, which permits unrestricted use, distribution, and reproduction in any medium, provided the original work is properly cited. 
transportation of non-biodegradable organic loads that utilize the available DO for chemical oxidation and microbial decomposition. While the enriched nitrite, nitrate and phosphate concentrations suggest enhanced productivity and influx of nutrients rich flood water from the anthropogenic source. Our study showed a coincidence in the highest brackish water height of the surface water $(1.24 \mathrm{~m})$ from the commodore channel with the highest groundwater level $(1.58 \mathrm{~m})$ in October. The lowest height of water levels was recorded in February and March at $2.23 \mathrm{~m}$ and $1.79 \mathrm{~m}$ for groundwater and surface water respectively. The similarities in the height of water levels were recorded with contrasting hydrochemical variables (e.g., high Ec vs. low Ec; and high Sal vs. low Sal), which confirmed the effect of rainfall/freshwater incursion on the surface water and simultaneous occurrence of subsurface pollution arising from seawater intrusion on the groundwater samples in October. This study had shown that a long term monitoring of rise in water levels and hydrochemical variables of surface and groundwater can be used to understand climate change and early warning predictions of flooding in coastal environments.

\section{Introduction}

In recent times, Nigeria coastal waters have been confronted with severe environmental challenges which have been identified as a cause of degradation of natural ecosystems, sea-level rise and saltwater intrusion into freshwater aquifers and drainage basins (Perera et al. [10]). The major economic consequences are the reduction in fishery productive capacity (that includes both capture and aquaculture); food security (Hall [3]) and serious health challenges to the inhabitants of the coastal region. Therefore, a longterm water quality monitoring, evaluation of the nutrient status, and the response of the Nigeria coastal waters to the gradual shifts in temperature; rainfall; storms; seawater/freshwater incursion and sea-level rise have become the concern of the Nigeria scientific community (Sayne [15]).

There is a need to incorporate the effects of global climate change to water resources management plan to accurately predict future hydrologic cycles, flooding, sea-level rise and its associated water quality parameters (Kumar [7]). Thus, improved understanding of the interrelationship of climate change and hydrological cycle, and its impacts in the coastal environment is urgently needed to develop adequate scientific and socioeconomic adaptation strategies and policies.

Lagos coastal areas represent one of the densely populated coastal provinces in the world with exacerbated pollution status that are triggered by series of coastal engineering projects, sand mining, channel dredging, marine debris, sewage disposal, wood logging, 
dredging and thermal pollution (Ajani et al. [1], Popoola et al. [11, 12], Olaniyi and Popoola [9], Ajani et al. [2]). The Lagos Harbour, within the commodore channel, has witnessed series of ocean forcing of tides and waves, and the accompanying high salinity values and electrical conductivity based on sea water incursion and proximity to the sea (Olaniyi and Popoola [9], Ajani et al. [2]).These series of oceanographic stressors tend to alter the physical and chemical characteristics of the coastal waters and cause an adverse health risk to the aquatic ecosystems.

This study aims to assess the seasonal variations in the physicochemical characteristics, nutrient status, and the variation in the height of surface water from the NIOMR jetty, within the commodore channel, south-west Nigeria. These data was also compared with the monitoring borehole sunk at $\sim 140 \mathrm{~m}$ from the NIOMR Jetty platform.

\section{Study Area}

The Harbour (Figure 1) situated in Lagos Lagoon axis, is Nigeria's most important seaport and the first inlet from the Atlantic Ocean, beyond the Republic of Benin (Popoola et al. [13]). It is one of the three main segments of Lagos Lagoon Complex; other segments are Metropolitan and the Epe Division Segments. It is $2 \mathrm{~km}$ wide and receives inland waters from the Lagos Lagoon in the north, and Badagry Creek in the west. Oil depots are located along the shore of western parts coupled with the proliferation of urban and industrial establishments on the shore of the eastern part. The long term monitoring processes were initiated (e.g., still in progress) on the brackish water samples in the NIOMR jetty station (Latitude $6^{\circ} 25^{\prime} 14,88^{\circ} \mathrm{N}$, Longitude $3^{\circ} 24^{\prime}$ $24,42^{\circ}$ E) located in the commodore channel of Lagos Harbour with Jetty facilities awaiting rehabilitation. A 200 feet monitoring borehole was also drilled at $\sim 140 \mathrm{~m}$ from the NIOMR Jetty platform for the basis of monitoring the effect of saline water intrusion and interrelationship between the surface and groundwater hydrochemistry. 


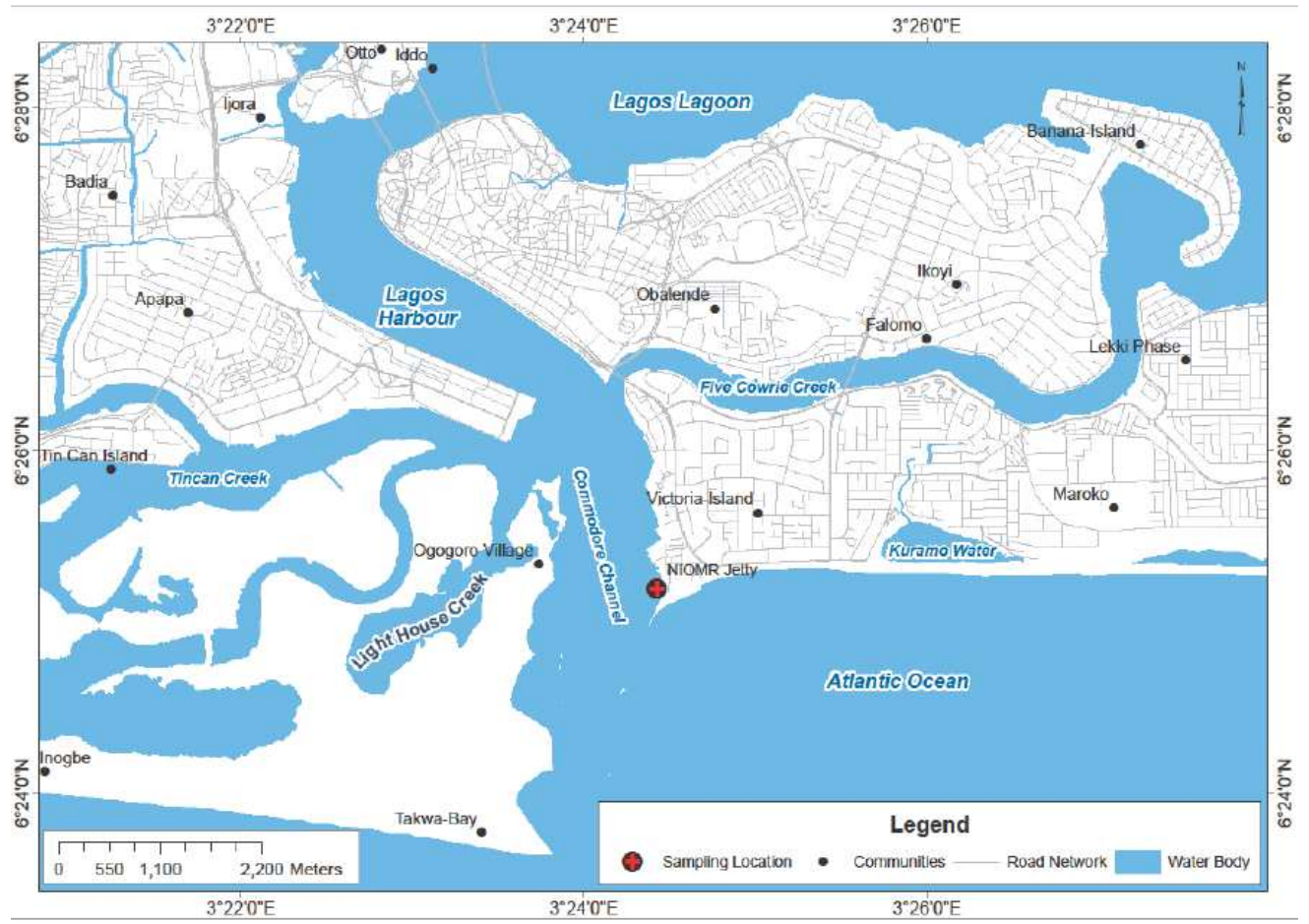

Figure 1. The Location Map of the study area showing NIOMR Jetty, the monitoring borehole was sunk at $\sim 140 \mathrm{~m}$ East from the NIOMR Jetty platform.

\section{Materials and Methods}

The sampling containers were pre-washed and rinsed with the surface water samples before sampling process. Samples were collected with a 1-litre pre-labelled plastic container, attached with $\sim 30$ feet rope. Water temperatures, $\mathrm{pH}$, electrical conductivity (Ec), and salinity (Sal) were measured in-situ at every sampling stations with Horiba U52 multi-water parameters. Separate water samples were collected in $250 \mathrm{ml}$ DO bottles and fixed with $2 \mathrm{mls}$ each of Winkler I (manganous-sulphate) and Winkler II (Alkaline Potassium Iodide) and titrated with sodium thiosulphate using starch as an indicator to determine dissolved oxygen according to Popoola et al. [12]. These processes were conducted daily from January to December 2019.

After the sampling process, Samples were analyzed for $\mathrm{pH}$, electrical conductivity (EC), salinity (SAL), dissolved oxygen (DO), and temperature (temp) daily from January to December 2019 (Table 1). Nitrite $\left(\mathrm{NO}_{2}{ }^{-}\right)$, nitrates $\left(\mathrm{NO}_{3}{ }^{-}\right)$, phosphate $\left(\mathrm{PO}_{4}{ }^{3-}\right)$, and sulphate $\left(\mathrm{SO}_{4}{ }^{2-}\right)$ were sampled for five months (August-November, 2019) and analysed 
using Smart Water Analysis Lab (LaMotte, MODEL SCL-05). Water level data were collected at the station from January-December 2019 using Hobo Water level logger (Model ANM30pq). The measurements were collected every 30 minutes and mean values over a month were stored, to obtain a monthly set of data.

\section{Results and Discussions}

Physicochemical characteristics of surface water samples

Tables 1-2 show the hydrochemical characteristics (e.g., sal, Ec, DO, temp, $\mathrm{pH}, \mathrm{NO}_{2}{ }^{-}$, $\mathrm{NO}_{3}{ }^{-}, \mathrm{PO}_{4}{ }^{3-}$, and $\mathrm{SO}_{4}{ }^{2-}$ ) of the surface water and its comparison with Federal Ministry of Environment Nigeria (FMNEV [5]) guidelines for coastal water. Table 3 shows the Pearson correlation coefficient of the hydrochemical characteristics. Figures 2-6 show the comparison of hydrochemical variables of surface and groundwater.

Table 1. Physicochemical characteristics of the surface water from the commodore channel.

\begin{tabular}{|c|c|c|c|c|c|c|}
\hline 3.07-6.05 Month & $\mathbf{p H}$ & $\mathbf{E c}(\boldsymbol{\mu S} / \mathbf{c m})$ & Sal $(\%)$ & Temp $\left({ }^{\mathbf{0}} \mathbf{C}\right)$ & DO (mg/L) & $\begin{array}{c}\text { Water } \\
\text { level (m) }\end{array}$ \\
\hline Jan & 7.99 & 47800 & 28.04 & 29.14 & 3.07 & 1.73 \\
\hline Feb & 8.05 & 46120 & 27.21 & 28.7 & 5.12 & 1.55 \\
\hline Mar & 8.13 & 47670 & 28.05 & 29.88 & 6.05 & 1.79 \\
\hline Apr & 8.17 & 47090 & 27.54 & 30.34 & 5.18 & 1.55 \\
\hline May & 8.19 & 46080 & 25.85 & 29.92 & 4.77 & 1.66 \\
\hline Jun & 8.33 & 23800 & 13.71 & 27.83 & 4.88 & 1.37 \\
\hline Jul & 8.31 & 15550 & 9.62 & 26.96 & 5.69 & 1.44 \\
\hline Aug & 8.17 & 22160 & 12.91 & 26.97 & 5.95 & 1.34 \\
\hline Sep & 8.21 & 22900 & 10.81 & 27.49 & 5.93 & 1.31 \\
\hline Oct & 8.3 & 9680 & 6.51 & 27.67 & 5.37 & 1.24 \\
\hline Nov & 8.48 & 21310 & 13.25 & 29.15 & 4.4 & 1.51 \\
\hline Dec & 8.28 & 29980 & 19.47 & 29.98 & 4.02 & 1.53 \\
\hline Range & $7.99-8.48$ & $9680-47800$ & $6.51-28.05$ & $26.97-30.34$ & $3.07-6.05$ & $1.24-1.79$ \\
\hline FMNEV [5] & $6.5-9$ & 900 & - & $<40$ & $>5.0$ & \\
\hline
\end{tabular}


Table 2. Nutrient concentration of the surface water from the commodore channel.

\begin{tabular}{|r|r|r|r|r|r|}
\hline & \multicolumn{1}{|c|}{$\begin{array}{c}\text { Nitrite } \\
(\mathrm{mg} / \mathrm{L})\end{array}$} & \multicolumn{1}{c|}{$\begin{array}{c}\text { Nitrate } \\
(\mathrm{mg} / \mathrm{L})\end{array}$} & \multicolumn{1}{c|}{$\begin{array}{c}\text { Sulphate } \\
(\mathrm{mg} / \mathrm{L})\end{array}$} & $\begin{array}{c}\text { Phosphate } \\
(\mathrm{mg} / \mathrm{L})\end{array}$ & \multicolumn{1}{c|}{$\begin{array}{c}\text { Depth } \\
(\mathrm{m})\end{array}$} \\
\hline Aug & 30 & 34 & 38 & 67 & 1.34 \\
\hline Sep & 23 & 32 & 41 & 44 & 1.31 \\
\hline Oct & 10 & 31 & 85 & 70 & 1.24 \\
\hline Nov & 20 & 28 & 79 & 22 & 1.51 \\
\hline Dec & 36 & 44 & 90 & 78 & 1.53 \\
\hline Range & $10-36$ & $28-44$ & $38-90$ & $22-78$ & $1.24-1.53$ \\
\hline FEMNV [5] & 1 & 20 & 500 & 5 & \\
\hline
\end{tabular}

Table 3. Pearson correlation matrix for the hydrochemical concentration of samples from the commodore channel.

\begin{tabular}{lllllllllll}
\hline & $\mathrm{pH}$ & $\mathrm{EC}$ & $\mathrm{Sal}$ & $\mathrm{Temp}$ & $\mathrm{DO}$ & Depth & $\mathrm{NO}_{2}^{-}$ & $\mathrm{NO}_{3}^{-}$ & $\mathrm{SO}_{4}^{-}$ & $\mathrm{PO}_{4}{ }^{-}$ \\
\hline $\mathrm{pH}$ & 1.00 & & & & & & & & & \\
$\mathrm{Ec}$ & -0.72 & 1.00 & & & & & & & \\
$\mathrm{Sal}$ & -0.70 & 0.99 & 1.00 & & & & & & & \\
$\mathrm{Temp}$ & -0.20 & 0.75 & 0.79 & 1.00 & & & & & & \\
$\mathrm{DO}$ & 0.10 & -0.29 & -0.34 & -0.44 & 1.00 & & & & & \\
$\mathrm{Depth}$ & -0.49 & 0.85 & 0.88 & 0.76 & -0.39 & 1.00 & & & & \\
$\mathrm{NO}_{2}^{-}$ & -0.44 & 0.80 & 0.67 & -0.02 & 0.10 & 0.39 & 1.00 & & & \\
$\mathrm{NO}_{3}^{-}$ & -0.42 & -0.55 & -0.74 & -0.97 & 0.94 & -0.79 & 0.01 & 1.00 & & \\
$\mathrm{SO}_{4}^{-}$ & 0.84 & 0.40 & 0.57 & 0.90 & -0.92 & 0.89 & -0.03 & -0.76 & 1.00 & \\
$\mathrm{PO}_{4}^{-}$ & -0.73 & -0.20 & -0.37 & -0.91 & 0.89 & -0.64 & 0.40 & 0.86 & -0.83 & 1.00 \\
\hline
\end{tabular}

*Correlation is significant at $P<0.05$ 


\subsection{Physicochemical characteristics}

The DO concentration ranges from 3.07-6.95mg/l and 4.77-5.93mg/l during the dry and wet season respectively (Table 1). The lowest $(3.07 \mathrm{mg} / \mathrm{l})$ and highest $(6.05 \mathrm{mg} / \mathrm{l}) \mathrm{DO}$ values were measured during the dry season in January and March respectively. The stipulated minimum benchmark level of DO for normal survival of marine ecosystem is $5.0 \mathrm{mg} / \mathrm{l}$ (Ladipo et al. [7]). The low $(<4.5 \mathrm{mg} / \mathrm{l})$ DO values in January, November and December could be attributed to erosion and transportation of non-biodegradable organic loads that often utilize the available DO for chemical oxidation and microbial decomposition The significant $(\mathrm{P}<0.05)$ positive correlation between DO and nitrate $(\mathrm{r}=0.94)$, and phosphate $(\mathrm{r}=0.89)$ (Table 3) suggest the influence of dissolved inorganic nutrients (nitrate and phosphate) on the solubility of oxygen in the commodore channel. The seasonal variation in the DO may also be attributed to nutrient availability, light penetrations and species of phytoplankton present during the sampling period.

The $\mathrm{pH}$ concentration ranges from 7.99-8.48 and 8.17-8.33 during the dry and wet season respectively (Table 1). The suitable $\mathrm{pH}$ values for marine life are in the range of 6-9 (FEPA [4], FMENV [5]) indicating fresh to alkaline (non-acidic) nature of the surface water during the sampling period. $\mathrm{pH}$ shows a significant positive correlation with sulphate $(\mathrm{r}=0.84)$ (Table 3$)$.

The water temperature ranges from $28.70-30.34^{\circ} \mathrm{C}$ and $26.96-29.92^{\circ} \mathrm{C}$ during the dry and wet season respectively (Table 1). The temperature falls within the range for a tropical climate environment and stipulated permissible limits (of $<40^{\circ} \mathrm{C}$ ) by FEPA [4] and FMENV [5]. There is an observed significant positive correlation among water temperature and water level $(\mathrm{r}=0.76)$ and sulphate $(\mathrm{r}=0.90)$ indicating similar influence in the three oceanographic variables in the commodore channel (Table 3). The variability in the temperature reflects the prevailing weather conditions during the sampling periods.

The electrical conductivity (Ec) is an essential parameter in ecology and water resources management, it is roughly proportional to the concentration of dissolved solids (mostly inorganic salts) there-in (Rukeh [14]). The Ec ranged from 21310-47800 $\mu \mathrm{s} / \mathrm{cm}$ and $9680-46080 \mu \mathrm{s} / \mathrm{cm}$ during the dry and wet season respectively, while the salinity concentrations range from $13.25-28.05 \%$ and $6.51-25.85 \%$ o during the dry and wet season respectively (Table 1). The lowest Ec $(9680 \mu \mathrm{s} / \mathrm{cm})$ and Sal (6.61\%o) concentrations were recorded in October (Table 1) followed by July with a value of $15550 \mu \mathrm{s} / \mathrm{cm}$ and $9.62 \%$ respectively. This indicates increase in freshwater incursion from the adjoining creeks or Lagos Lagoon, or dilution arising from rainfall. The high Ec 
and Sal values during the dry season may be related to a reduced dilution from reduced rainfall and freshwater incursion.

\subsection{Seasonal trends in the brackish water level and hydrochemistry}

The brackish water-level varies from 1.51-1.66m and $1.24-1.79 \mathrm{~m}$ during the wet and dry season respectively (Table 2$)$. The lowest water level $(1.79 \mathrm{~m})$ occurred in March during the dry season, which coincides with the highest DO values $(6.05 \mathrm{mg} / \mathrm{L})$, enriched salinity $(28.05 \%$ o) and electrical conductivity $(47670 \mu \mathrm{s} / \mathrm{cm})$ in the same month. Meanwhile, the lowest water level $(1.66 \mathrm{~m})$ during the wet season occurred in May (Table $2)$. The highest water level $(1.24 \mathrm{~m})$ occurred in October (during the wet season), and coincides with the lowest electrical conductivity $(9680 \mu \mathrm{s} / \mathrm{cm})$ and salinity $(6.51 \%)$ in the same month (Table 2).

The correlation between the lowest water level and highest DO value in March may be related to a reduced erosion or transportation of non-biodegradable organic loads that often utilize the available DO for chemical oxidation and microbial decomposition (Ibanga et al. [6]). The reduced transportation of these non-biodegradable organic loads thus tends to enhance the DO values in March. Meanwhile, the coincidence between lowest brackish water level and enriched Sal and Ec in March may be related to a reduction in the dilution of the dissolved inorganic salts and reduced rainfall, erosion and transportation of freshwater effluents in March. The coincidence between the highest brackish water level $(1.24 \mathrm{~m})$ and the lowest Sal and Ec values of $6.51 \%$ and $9680 \mu \mathrm{s} / \mathrm{cm}$ respectively can also be attributed to the influence of dilution of dissolved inorganic salts from rainfall or increased freshwater incursion from the adjoining creeks or Lagos Lagoon. The significant positive correlation between nitrite and electrical conductivity $(\mathrm{r}=0.80)$; nitrite and salinity $(\mathrm{r}=0.67)$; sulphate and salinity $(\mathrm{r}=0.57)$; sulphate and water level ( $\mathrm{r}=0.89)$; phosphate and nitrate $(\mathrm{r}=0.86)$ (Table 3) affirm the influence of rainfall/freshwater incursion on the physicochemical characteristics. The comparison of the dissolved inorganic anions (nitrite, nitrate, sulphate and phosphate) with depth from August to December 2019 showed that the highest concentration of nitrite $(36 \mathrm{mg} / \mathrm{l})$, nitrate $(44 \mathrm{mg} / \mathrm{l})$, sulphate $(90 \mathrm{mg} / \mathrm{l})$ and phosphate $(78 \mathrm{mg} / \mathrm{l})$ in December correspond to the lowest water level $(1.53 \mathrm{~m})$ in December (Table 2). The relationship between the brackish water level and the anions further support the influence of ebb-flood tidal flows (i.e. seawater incursion during flood flow and freshwater dilution during ebb flow) on the dissolved inorganic anions of commodore channel. The nitrite, nitrate and phosphate levels exceeded the stipulated minimum benchmark for coastal waters in Nigeria (Table 
2 ), which indicate enhance productivity or influx of nitrogen-rich flood water from domestic sewage, municipals discharge or animal manure used on cropland.

\subsection{Interrelationship between surface and groundwater levels and the physicochemical characteristics}

The $\mathrm{pH}$ values of the surface water from the commodore channel showed a higher range of values compared to the monitoring borehole at the NIOMR jetty (Figure 2), although both fall within alkaline $\mathrm{pH}$ values. The $\mathrm{pH}$ values showed similar trends with the highest values in November (dry season), and a sharp drop in $\mathrm{pH}$ values by December and January.

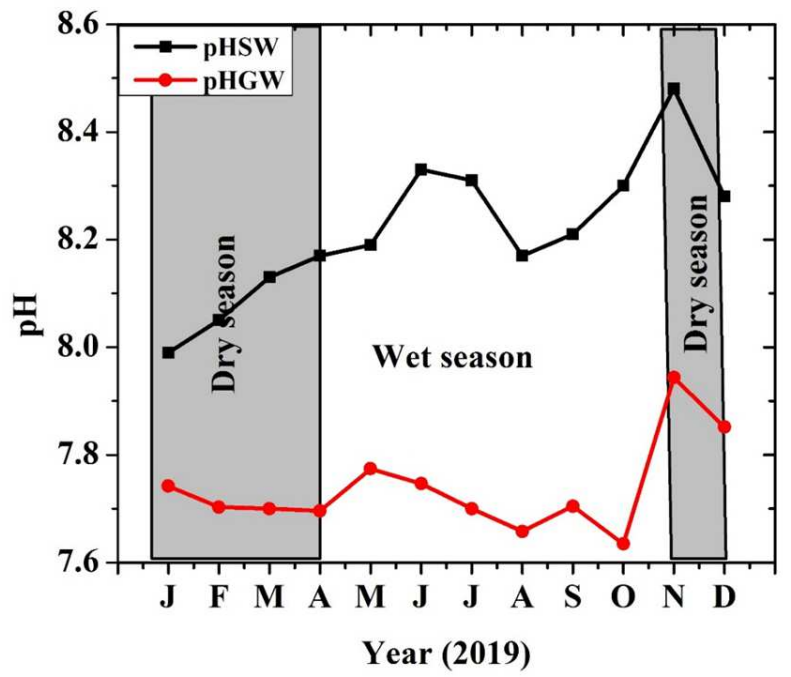

Figure 2. Comparison of the Seasonal variation in $\mathrm{pH}$ of the brackish surface water at the commodore channel and the monitoring borehole at the NIOMR jetty. SW: surface water, GW: groundwater.

The electrical conductivity levels of the surface water showed a significant variation when compared with the groundwater (Figure 3), however, the lowest conductivity values $(9680 \mu \mathrm{S} / \mathrm{cm})$ in October from the surface water coincides with the highest conductivity values $(3972 \mu \mathrm{S} / \mathrm{cm})$ in the groundwater in the same month. Additionally, the highest water level $(1,24 \mathrm{~m})$ in surface water from the commodore channel in October coincides with the highest water level $(1.58 \mathrm{~m})$ in the same month (Figure 4$)$. The lowest water level of the surface water $(1.79 \mathrm{~m})$ from the commodore channel and groundwater $(2.23 \mathrm{~m})$ from the NIOMR Jetty were recorded in March and February respectively (Figure 4). 


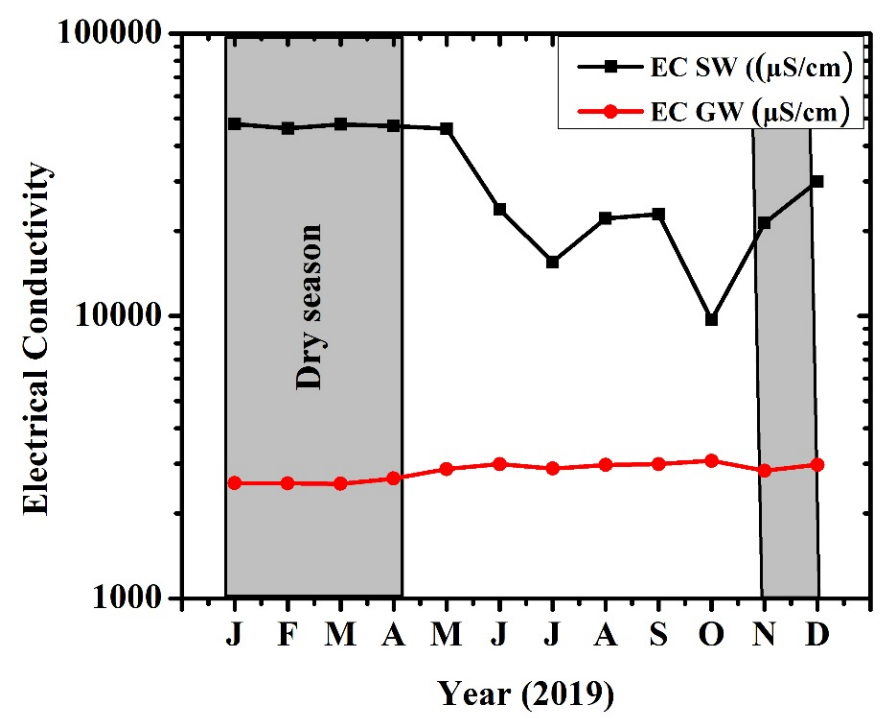

Figure 3. Comparison of the seasonal variation in concentration of the electrical conductivity (EC) of the brackish surface water at the commodore channel and the monitoring borehole at the NIOMR jetty. SW: surface water, GW: groundwater.

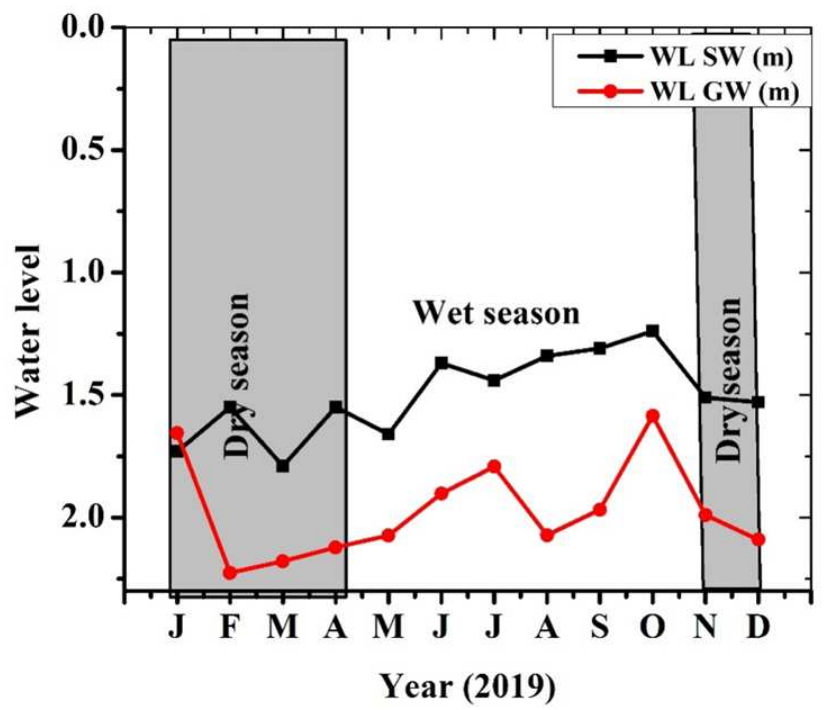

Figure 4. Comparison of the seasonal variation in the height of brackish water level of surface water at the commodore channel and the water level of the monitoring borehole at the NIOMR jetty. SW: surface water, GW: groundwater. 


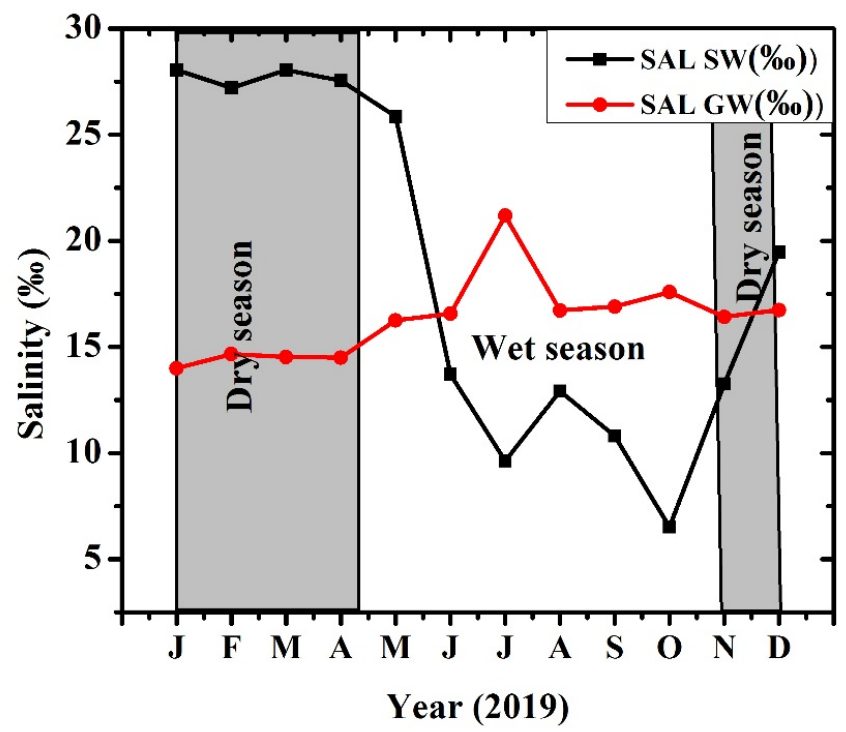

Figure 5. Comparison of the seasonal variation in concentration of the salinity (SAL) of the brackish surface water at the commodore channel and the monitoring borehole at the NIOMR jetty. SW: surface water, GW: groundwater.

These opposite trends in the conductivity levels from the surface and groundwater and similarities in the water level height in October support the aforementioned influence of ebb-flood tidal flows. These interrelationships can be simply explained as freshwater dilution of the surface brackish water from the commodore channel (creating low Ec and Sal concentrations) and the corresponding subsurface migration and infiltration of seawater into the groundwater aquifer, thus creating high Ec and Sal concentrations in the monitoring borehole at the NIOMR jetty (Figures 4 and 5). This occurrence further affirmed the aforementioned freshwater dilution of the brackish surface water from the commodore channel and the corresponding subsurface infiltration of saline water from the brackish water, into the monitoring borehole, or probably from other external source.

The water temperature (Figure 6) showed similar trends from January to June, but opposite trends from August to October, which may be attributed to the changing weather conditions and the confined nature of the groundwater. 


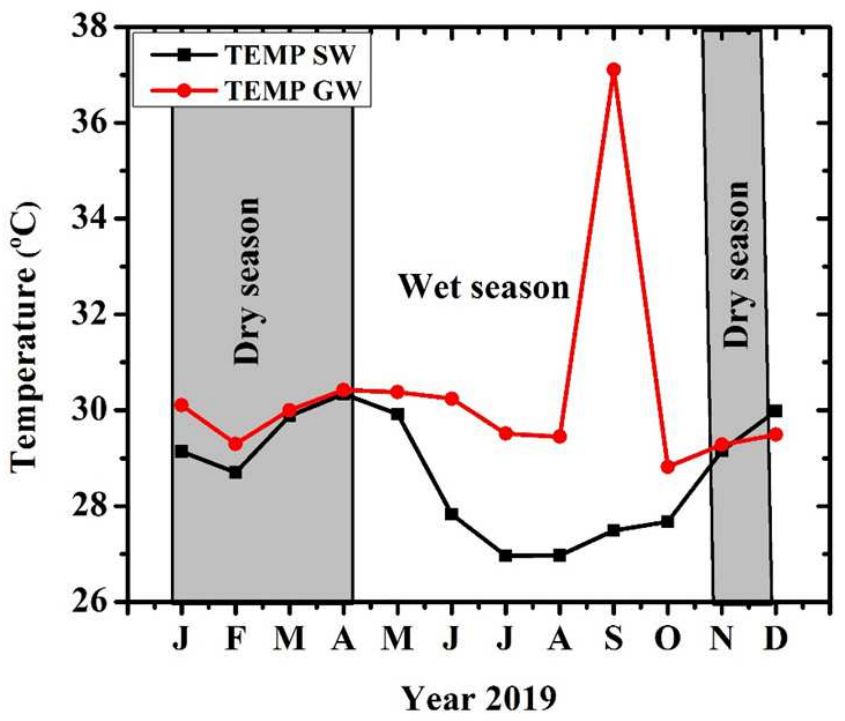

Figure 6. Comparison of the seasonal variation in water temperature (TEMP) of the brackish surface water at the commodore channel and the monitoring borehole at the NIOMR jetty. SW: surface water, GW: groundwater.

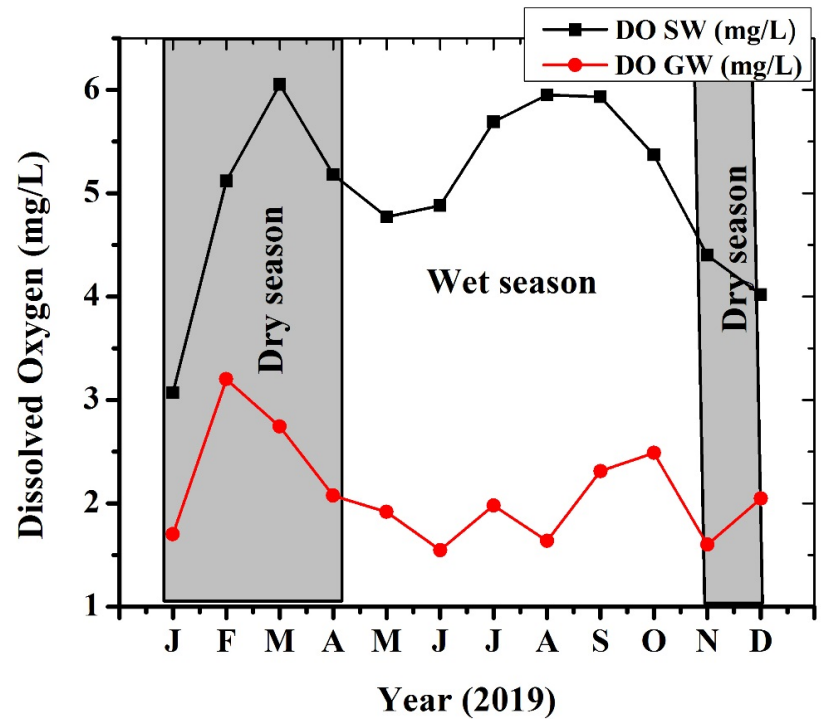

Figure 7. Comparison of the seasonal variation in dissolved oxygen (DO) of the brackish surface water at the commodore channel and the monitoring borehole at the NIOMR jetty. SW: surface water, GW: groundwater. 
The DO of the surface brackish water also showed similar trends with DO values of the groundwater, with corresponding high values in March and February for the surface and groundwater respectively (Figure 7).

\section{Conclusion}

The main objective of this study was to assess the seasonal variations in the physicochemical characteristics, nutrient status, and variation in the height of the brackish water level of surface water from the commodore channel. The data from the surface water was also compared with the monitoring borehole sunk at approximately $140 \mathrm{~m}$ from the NIOMR Jetty platform. We studied the changes in the height of the water level, physicochemical properties ( $\mathrm{pH}$, electrical conductivity (Ec), salinity (Sal), dissolved oxygen (DO), and temperature (temp) from January to December in 2019. The nutrients (nitrite, nitrates, phosphate, and sulphate) distributions of the surface water were also analysed from August to December 2019.

The hydrochemical characteristics of the surface water all through the year 2019 were within the minimum stipulated limit by Federal Ministry of Environment (FMNEV), with the exception low $(<4.5 \mathrm{mg} / \mathrm{l})$ DO values in January, November and December and high nitrite, nitrate and phosphate values across the season. The low DO values may be attributed to enhanced transportation of non-biodegradable organic loads that often utilize the available DO for chemical oxidation and microbial decomposition in January, November and December. The enriched nitrite, nitrate and phosphate concentrations suggest enhanced productivity or influx of nutrients rich flood water from domestic sewage, or municipals discharges.

The highest water level $(1.24 \mathrm{~m})$ in surface water from the commodore channel in October correspond to the highest water level $(1.58 \mathrm{~m})$ in the same month with opposite trends in their dissolved inorganic ions (nitrite, nitrate, sulphate and phosphate), conductivity and salinity concentrations. Our studies further showed the influence of freshwater dilution on the hydrochemistry of surface water from the commodore channel, and seawater intrusion on the hydrochemical characteristics of the groundwater of the NIOMR Jetty.

The influence of seawater intrusion and freshwater dilution on the hydrochemical variables had further shown that a long term monitoring of physicochemical characteristics and height of surface and groundwater levels can be used to understand climate change and early warning predictions of flooding in coastal environments. 


\section{Acknowledgments}

The authors wish to acknowledge other researchers in the Department of Physical and Chemical Oceanography of the Nigerian Institute for Oceanography and Marine Research (NIOMR) for their cooperation during the sampling period. We are particularly grateful to the management of NIOMR for their support during the take-off of this project.

\section{References}

[1] G.E. Ajani, K.I. Oshisanya, S.O. Popoola and P.O. Oyeleke, Heavy metal pollutions and its associated ecological risks in Lagos lagoon sediments, South-western Nigeria, American Chemical Science Journal 9(3) (2015), 1-13.

https://doi.org/10.9734/ACSJ/2015/20334

[2] G.E. Ajani, S.O. Popoola and O.O. Oyatola, Evaluation of the pollution status of Lagos coastal waters and sediments, using physicochemical characteristics, contamination factor, Nemerow pollution index, ecological risk and potential ecological risk index, International Journal of Environments and Climate Change (2020), to appear.

[3] G.M. Hall, Impact of climate change on aquaculture: the need for alternative feed components, Turkish Journal of Fisheries and Aquatic Sciences 15 (2015), 569-574. http://doi.org/10.4194/1303-2712-v15_2_45

[4] FEPA, Federal Environmental Protection Agency, Guidelines and Standards for Environmental Pollution Control in Nigeria, Federal Environmental Protection Agency, Lagos, 1991.

[5] FMENV, National Guidelines and Standards for Water Quality in Nigeria, Federal Ministry of Environment, 2001.

[6] L.B. Ibanga, J.A. Nkwoji, A.I. Usese, I.C. Onyema and L.O. Chukwu, Hydrochemistry and heavy metals concentrations in sediment of Woji creek and Bonny estuary, Niger Delta, Nigeria, Regional Studies in Marine Science 25 (2019), 100436. https://doi.org/10.1016/j.rsma.2018.10.004

[7] C.P. Kumar, Climate change and its impact on groundwater resources, International Journal of Engineering and Science 1(5) (2012), 43-60.

[8] M.K. Ladipo, V.O. Ajibola and S.J. Oniye, Seasonal variations in physicochemical properties of water in some selected locations of the Lagos Lagoon, Science World Journal 6(4) (2011), 5-11.

[9] S.R. Olaniyi and S.O. Popoola, Distributions of heavy metals and total organic carbon of 
surface and sediment cores collected from Lagos coastal waters, South-West Nigeria: impact of human-induced anthropogenic activity, Asian Journal of Environment and Ecology (2020), to appear.

[10] M.D.N.D. Perera, T.K.G.P. Ranasinghe, R.U.K. Piyadasa and G.Y. Jayasinghe, Risk of seawater intrusion on coastal community of Bentota river basin Sri Lanka, Procedia Engineering 212 (2018), 699-706.

[11] S.O. Popoola, M.P. Ibitola, Y.P. Appiah and M.I. Titocan, Geochemical and statistical approach to assessing trace metal accumulations in Lagos Lagoon Sediments, SouthWestern, Nigeria, Journal of Geography Environment and Earth Science International 3(4) (2015a), 1-16. https://doi.org/10.9734/JGEESI/2015/20333

[12] S.O. Popoola, U. Udochu, F.O. Adekunbi, C.J. Nwoko and A.O. Fashade, Spatial Variations in the physicochemical parameters of some selected locations in Lagos Lagoon, South-Western Nigeria, Journal of Science 5(12) (2015b), 1354-1359.

[13] S.O. Popoola, O.A. Nubi, O.O. Oyatola, F.O. Adekunbi, G.I. Fabunmi and C.J. Nwoko, Vertical profiling and contamination risk assessment of some trace metals in Lagos Lagoon axis, International Journal of Science, Technology and Society 3(4) (2015c), 156-163. https://doi.org/10.11648/j.ijsts.20150304.19

[14] A. Rim-Rukeh, Physico-chemical and biological characteristics of stagnant surface water bodies (ponds and lakes) used for drinking and domestic purposes in Niger Delta, Nigeria Journal of Environmental Protection 4 (2013), 920-928.

https://doi.org/10.4236/jep.2013.49106

[15] A. Sayne, Climate Change Adaptation and Conflict in Nigeria, Special Report 274, by United States Institute of Peace, 2011. https://www.usip.org/sites/default/files/Climate_Change_Nigeria.pdf 